\author{
UNIVERSITY OF MINNESOTA \\ ST. ANTHONY FALLS HYDRAULIC LABORATORY
}

Project Report No. 364

\title{
Extreme Value Analysis of a Fish/Temperature Field Database
}

\author{
by \\ Heinz G. Stefan and Midhat Hondzo \\ St. Anthony Falls Hydraulic Laboratory \\ University of Minnesota, Minneapolis, MN \\ and
}

John G. Eaton and Howard McCormick Environmental Research Laboratory, Duluth, MN

U.S. Environmental Protection Agency

Prepared for

U.S. ENVIRONMENTAL PROTECTION AGENCY

Environmental Research Laboratory

Duluth, MN 55804

St. Paul, Minnesota

November 1994 
The University of Minnesota is committed to the policy that all persons shall have equal access to its programs, facilities, and employment without regard to race religion, color, sex, national origin, handicap, age, or veteran status. 


\begin{abstract}
Extreme water temperatures limit the presence of fish species in streams and lakes. Upper extreme water temperatures and their uncertainties are determined by several statistical methods from a large field database. There are over 140,000 weekly mean fish/stream temperature matched pairs in the database. Three different techniques are employed to estimate upper extreme habitat temperatures of 24 fish species. To quantify the uncertainty of the estimated extreme temperatures the bootstrap method, the method of moments and the residual method are applied. The data above the maximum growth temperature matched well by a type III extremal or a three-parameter lognormal distribution. Standard error of the estimated extreme habitat temperatures depends on species and varies from $0.1^{\circ} \mathrm{C}$ to $0.6^{\circ} \mathrm{C}$ at the $95 \%$ cumulative probability of occurrence.
\end{abstract}





\section{Table of Contents}

Page No.

$\begin{array}{lr}\text { Abstract } & \text { i } \\ \text { List of Figures } & \text { iv } \\ \text { List of Tables } & \text { v }\end{array}$

1. Introduction 1

2. Methods 3

2.1. FTDMS database 3

2.2. Extreme temperature computation procedure 3

2.2.1. Maximum 95th percentile weekly water temperature 3

2.2.2. Parametric method 5

2.2.3. Bootstrap method 10

2.3. Extreme temperature uncertainty estimation 11

2.3.1. Method of moments 11

2.3.2. Bootstrap method 11

2.3.3. Residual method 11

2.3.4. Confidence interval 12

3. Results 13

3.1. Extreme temperature computation 13

3.1.1. Maximum 95th percentile weekly temperatures 13

3.1.2. Probability distribution fitted to temperatures above maximum growth temperature

3.1.3. 95th and 99th percentile temperatures above maximum growth temperature 20

3.2. Uncertainty of extreme temperature computation 20

3.2.1. Method of moments 20

3.2.2. Bootstrap method 24

3.2.3. Residual method 24

4. Discussion 26

Acknowledgement $\quad 28$

$\begin{array}{ll}\text { References } & 29\end{array}$ 


\section{List of Figures}

Fig. 1 Fish/temperature observations for walleye in the Fish Temperature Database Management System (FTDMS). (a) All data and week with maximum weekly $95 \%$ FTDMS temperature (b) Data above maximum growth $\left(\mathrm{T}_{\mathrm{opt}}\right)$ temperature (c) Residual data above weekly 95\% FTDMS temperature.

Fig.2a Cumulative probability distributions. Fitted values are denoted by solid lines. Values derived from the FTDMS are denoted by dashed lines.

Fig.2b Cumulative probability distributions. Fitted values are denoted by solid lines. Values derived from the FTDMS are denoted by dashed lines.

Fig.2c Cumulative probability distributions. Fitted values are denoted by solid lines. Values derived from the FTDMS are denoted by dashed lines.

Fig.3a Quantile-quantile plots for distributions fitted by method of moments to fish/temperature pairs in the FTDMS. Horizontal axes are observed and the vertical axes are fitted temperatures. The solid line would be a perfect fit.

Fig.3b Quantile-quantile plots for distributions fitted by method of moments to fish/temperature pairs in the FTDMS. Horizontal axes are observed and the vertical axes are fitted temperatures. The solid line would be a perfect fit.

Fig.3c Quantile-quantile plots for distributions fitted by method of moments to fish/temperature pairs in the FTDMS. Horizontal axes are observed and the vertical axes are fitted temperatures. The solid line would be a perfect fit.

Fig. 4 Standard errors of temperature estimates for different cumulative probabilities or excedance levels above maximum growth temperature. 


\section{List of Tables}

Table 1 Fish species/temperature statistics.

Table 2 95\% and 99\% temperatures and standard errors of these water temperatures as determined by the bootstrap method and by the fitted cumulative probability function (parametric) method to temperature data (samples) above maximum growth temperature.

Table 3 Standard errors of 95\% FTDMS water temperatures as determined by analysis of residuals above $95 \%$ FTDMS values. 


\section{Introduction}

Among the many parameters which influence fish growth, survival and reproduction, water temperature may be the most fundamental. To quantify the relationships between water temperatures and fish responses, laboratory experiments are often conducted but exposure conditions in the laboratory environment are far less complex than those that occur in nature. To avoid the uncertainties associated with not knowing the ecological significance of laboratory derived values, the United States Environmental Protection Agency Environmental Research Laboratory-Duluth (USEPA/ERLD) has assembled an extensive field data base (Fish and Temperature Database Matching System, FTDMS) in which field observations of 29 fish species are paired with mean weekly water temperature measurements made in the same stream-reaches. There are now 141,208 "Fish/Temperature (F/T) matched pairs" in that database. The development of that database and its present status is the topic of a recent paper by Eaton et al. (1995). Upper extreme habitat temperatures (UEHT) for the various fishes can be estimated from the FTDMS. For example, following an approach by Biesinger et al. (1979) the highest 95 percentile value of the warmest week was selected as the maximum temperature value at which a fish species or guild would be present in a water body. This approach was also followed by Eaton et al. (1995) except that the highest 5 percent of all field data are used instead of the warmest week. Using the 95th percentile seemed appropriate (instead of the 100 percentile) in light of the wide geographic data distribution and the range of time-scales over which measurements had been made. Possible sources of error such as measurement errors, fish presence due to refugia, and lack of temporal correspondence of fish and temperature records affect the database. Upper extreme habitat temperatures obtained in this way compare favorably with laboratory test results involving exposures of several days (e.g. FTDMS 95 percentile values are mostly $1^{\circ}$ to $3^{\circ} \mathrm{C}$ lower than acute mortality temperatures), but comparable to upper zero net growth temperatures (Stefan et al. 1992). The presence or absence of a fish species or guild does not imply a direct relationship to mortality because the upper lethal temperature is strongly related to changes in physiology at high temperatures which can only be studied in laboratory experiments.

This paper examines alternative methods for estimating upper extreme habitat temperatures field data. The primary goal is to illustrate the applicability and usefulness of some extreme value theories to the statistical analysis of extreme temperatures for fish presence or absence. In so doing a special effort is made to quantify the degree of uncertainty of the estimated extreme temperatures. To do this 
three different techniques are employed, i.e., the method of moments, the bootstrap method, and the residual method. 


\section{Methods}

\subsection{FTDMS database}

The data analyzed herein are mean weekly water temperatures obtained from stream sites at widely dispersed locations within the conterminous U.S. All fish observations used in these fish presence/ambient temperature matches were made within a stream reach adjacent to the temperature gauging station. The fish observations were made at any time of the year. Fish presence observations within a year are matched temporally with stream weekly mean water temperatures for that same year to create "F/T matched pairs". To be accepted for creating an F/T dataset, each selected fish collection station to be matched with a water temperature data entry must be (Eaton et al. 1995): (1) on the same branch of a river as the temperature station, (2) within $15 \mathrm{~km}$ of the temperature station, and (3) with no tributaries joining the river branch between the two stations, as determined by the Geographic Information System coverage of major rivers and streams in the area. Separate data are kept for each species.

For most species database contains water temperatures beginning at $0^{\circ} \mathrm{C}$ and extends to the maximum recorded for that species. Figure 1a displays as an example the $\mathrm{F} / \mathrm{T}$ sets for the walleye. To determine the upper extreme temperature for a species, the lower temperatures were excluded as irrelevant. Exclusion of lower temperatures was done differently by each of the methods to be discussed. The following describes how, why and the consequences of the three methods used.

\subsection{Extreme temperature computation procedure}

\subsubsection{Maximum 95th percentile weekly water temperature}

An upper extreme habitat temperature for each fish species was estimated following the approach suggested by Biesinger et al. (1979). The estimated values are given for example by Stefan et al. (1992). The 95th percentile of the FTDMS temperatures for each week is estimated during the entire year. The week with the largest measured 95th percentile (shaded box in Fig. 1a) was retained for further analysis. The 95th percentile of this week is then identified as the UEHT for the particular fish species. The foregoing procedure is simple, but requires large database. It is, however, not the only method by which an extreme habitat temperature can be 


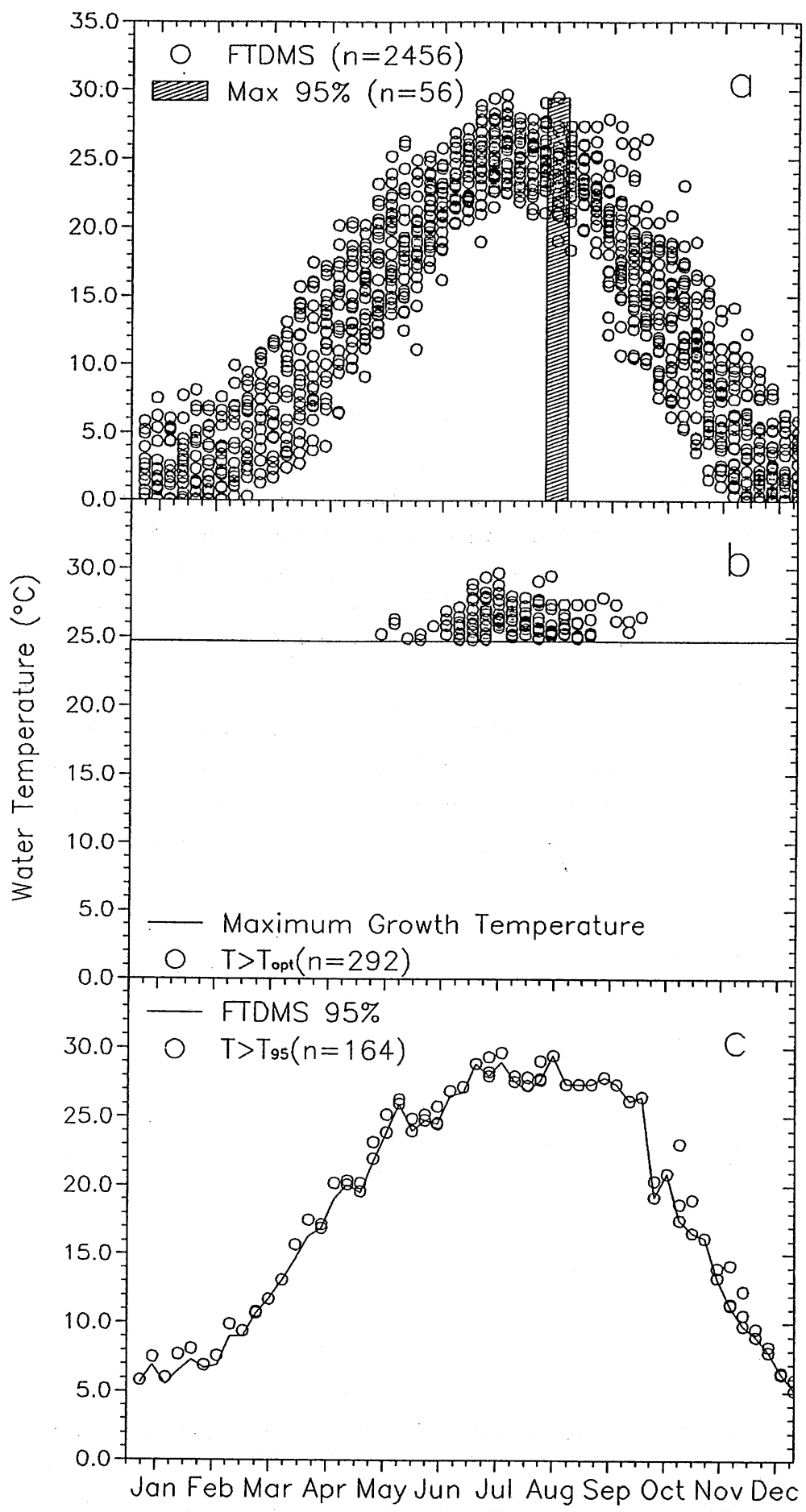

Fig. 1 Fish/temperature observations for walleye in the Fish Temperature Database Management System (FTDMS). (a) All data and week with maximum weekly $95 \%$ FTDMS temperature (b) Data above maximum growth $\left(\mathrm{T}_{\mathrm{opt}}\right)$ temperature (c) Residual data above weekly $95 \%$ FTDMS temperature. 
estimated from the database. We shall examine some alternatives, and explain their respective advantages and disadvantages.

\subsubsection{Parametric method}

A visual examination of the FTDMS database example in Fig. 1a shows that by analyzing the data week by week and selecting only the week with the highest 95 th percentile FTDMS temperature, many high temperature values fail to make a contribution to the calculated UEHT. This is especially disturbing when the variability or confidence interval of the 95th percentile FTDMS temperature is determined.

This real or perceived loss in information in the week by maximum weekly analysis is remedied in the "threshold series" method. In this method, all temperatures above a certain base (threshold) magnitude are retained for the extreme temperature analysis of the particular fish species. The threshold magnitude is herein taken as the maximum growth (optimum) temperature, i.e., all temperatures above the maximum growth temperature are included in the analysis (Fig. 1b). The maximum growth temperature is considered as a meaningful threshold, because water temperatures above the maximum growth temperature affect fish growth adversely. Estimates of maximum growth temperatures for different fish species reported in the literature are given in Table 1 . The actual value of the maximum growth temperature has only small relevance, because only the extreme upper end of the data is crucial to the analysis. Therefore a guild mean can be used, if the optimum growth temperature is unknown for a fish species, without changing the results of the analysis.

Continuous probability distributions are used to define the magnitude of the extreme temperature corresponding to a given cumulative probability for the particular fish species. To fit probability or frequency distributions to the data (above the optimum temperature) two steps were necessary: (1) to find a probability distribution, if any, which follows the data, and (2) to estimate the parameters of the chosen probability distribution in order to minimize the differences between observed and fitted temperatures. The data in the FTDMS are only a sample in time and space, and subject to measurement errors, thus the fitting procedure must minimize these errors in an efficient way.

Four probability distributions, i.e., type III extremal distribution (T3E), threeparameter lognormal (LN3), Pearson type III, and log-Pearson type III distributions were considered potential candidates for the analysis. The type III extremal distribution or the three parameter log-normal distributions were found to give the best fits for all fish species (Figs 2a, 2b, and 2c). The type III extremal cumulative probability distribution function is 


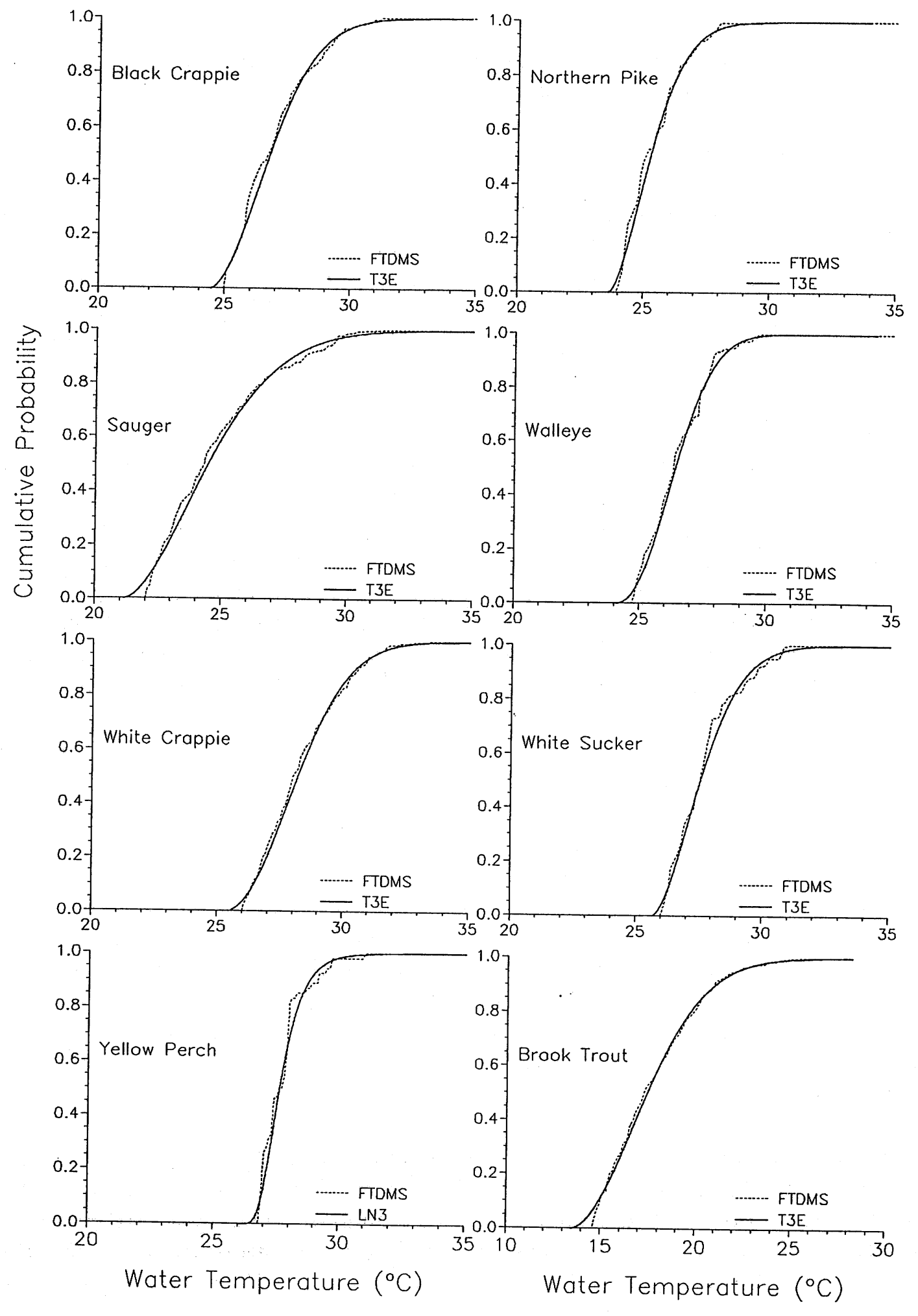

Fig.2a Cumulative probability distributions. Fitted values are denoted by solid lines. Values derived from the FTDMS are denoted by dashed lines. 


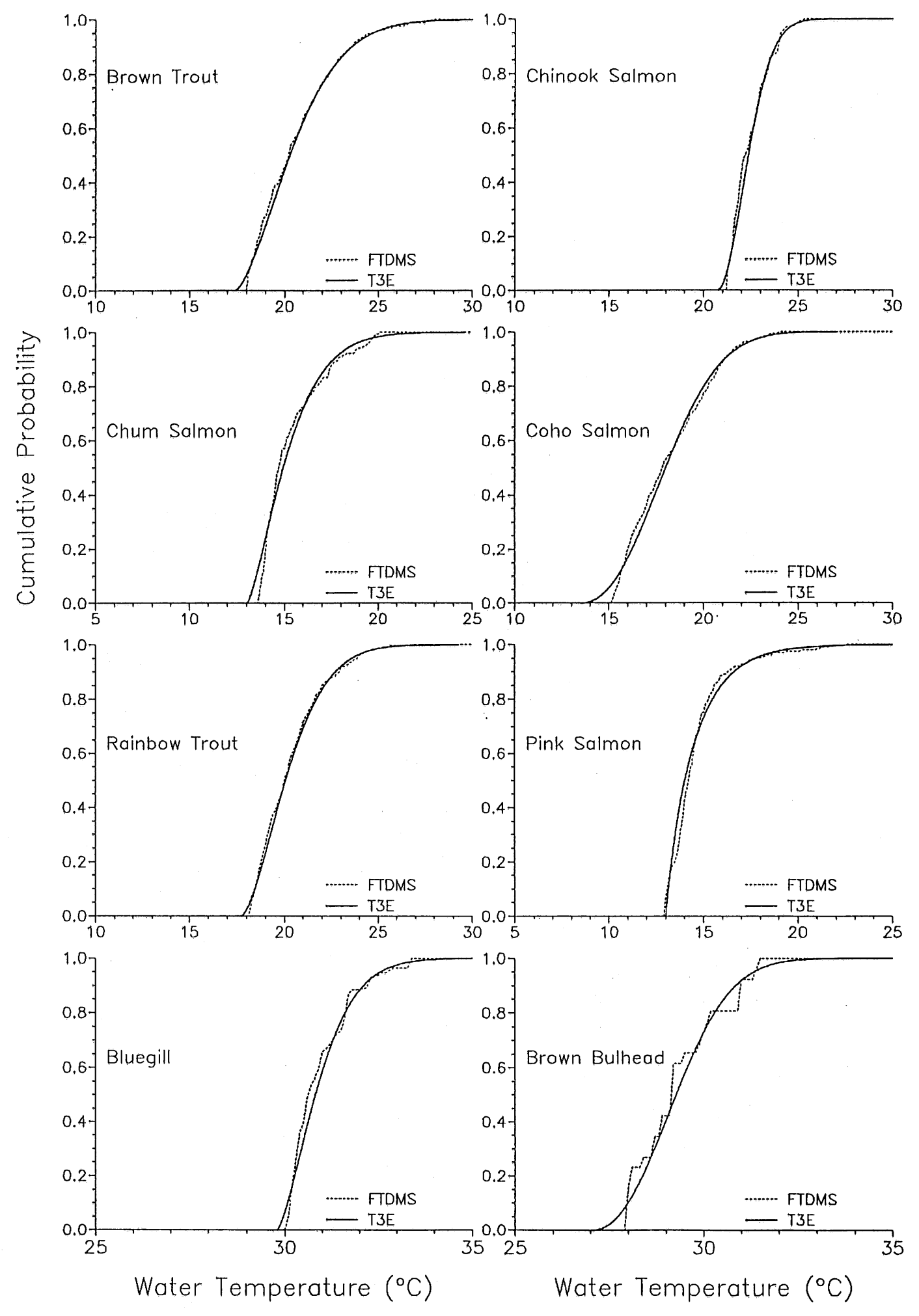

Fig.2b Cumulative probability distributions. Fitted values are denoted by solid lines. Values derived from the FTDMS are denoted by dashed lines. 


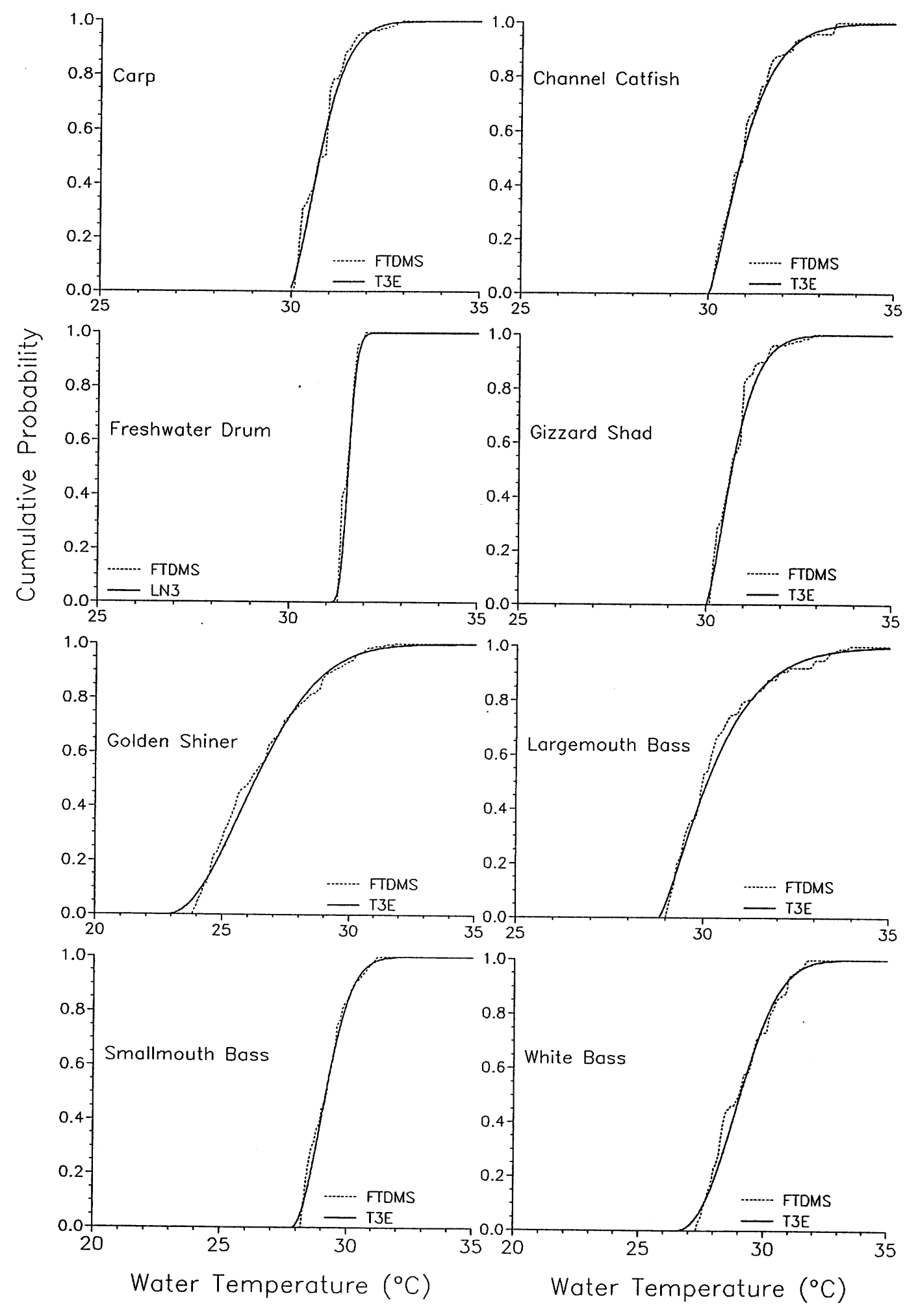

Fig.2c Cumulative probability distributions. Fitted values are denoted by solid lines. Values derived from the FTDMS are denoted by dashed lines. 


$$
P(x)=1-\exp ^{-\left(\frac{x-y}{p-\gamma}\right)^{\alpha}}
$$

and the probability density function is

$$
p(x)=\frac{\alpha}{\beta-\gamma}\left(\frac{x-\gamma}{\beta-\gamma}\right)^{\alpha-1} \exp -\left(\frac{x-\gamma}{\beta-\gamma}\right)^{\alpha}
$$

where $\alpha$ is the scale parameter equal to the order of the lowest derivative of the probability function that is not zero at $x=\gamma$ (Kite, 1986), $\beta$ is the characteristic temperature (location parameter), and $\gamma$ is the lower limit to the water temperature (variable $\mathrm{x}$ ). The probability density function for the three-parameter lognormal distribution is

$$
p(x)=\frac{1}{(x-a) \sigma_{y} \sqrt{2 \pi}} \exp ^{-\frac{\left[\ln (x-a)-\mu_{y}\right]^{2}}{2 \sigma_{y}^{2}}}
$$

where $\sigma_{\mathrm{y}}{ }^{2}$ is the scale parameter (variance of the logarithms of $(\mathrm{x}-\mathrm{a})$ )), $\mu_{\mathrm{y}}$ is the form parameter (mean of the logarithms of (x-a)), and 'a' is the lower boundary of $x$. The cumulative probability distribution was obtained numerically because equation 3 is not analytically integrable.

The method of moments and the method of maximum likelihood (Haan, 1977; Kite, 1988) were used as techniques for the parameter estimation for the particular distributions. Two criteria were used for the probability distribution acceptance. The first is goodness of fit between the observed and predicted (fitted) temperatures

$$
r^{2}=1-\frac{\sum_{i=1}^{N}\left(T_{f i t}-T\right)^{2}}{\sum_{i=1}^{N}(T-\bar{T})^{2}}
$$


where $T_{\text {fit }}$ is fitted temperature, $T$ is observed temperature, $T$ is an average of the observed temperature, and $\mathrm{N}$ is the total number of data above the optimum temperature. The second criterion was introduced in order to examine qualitatively the upper end of the probability distribution, i.e., the region where the upper thermal tolerance limit is most likely to occur. For this purpose the quantile-quantile (QQ) plots (Graedel and Kleiner, 1985) were used. The corresponding point on the QQ plots is given by the coordinate pair

$$
Q Q(i)=\left[F^{-1}\left(\frac{n}{N}\right) ; x(i)\right]
$$

where $\mathrm{i}$ is the coordinate number, $\mathrm{F}^{-1}$ is the inverse of the theoretical probability distribution, $\mathrm{n}$ is the number of observed temperatures for a particular class, $\mathrm{N}$ is the total number of temperatures above the optimum temperature for a particular species, and $x(i)$ is the observed temperature. In simple words, the first term in the square bracket is fitted (predicted) and the second term is observed temperature. A perfect fit would be indicated by all points being on the line with a slope of 1:1.

\subsubsection{Bootstrap method}

The bootstrap method extends the basic idea of an estimate for the accuracy of the mean, i.e., standard deviation, to any estimator (Efron and Gong, 1983). An estimator is customarily defined as a procedure for deriving an estimate from a sample. We are concerned with extreme (95th percentile) temperatures; therefore, the method was applied to the 95th percentile estimator. For each fish species a bootstrap sample was drawn 1000 times and the 95th percentile estimator was computed as

$$
\hat{T}_{95}^{B}=\frac{\sum_{b=1}^{B} \hat{T}_{95}^{b}}{B}
$$

where $b=1$ is the first draw from the fish bootstrap sample, and $B$ is the total number of the bootstrap draws. Note that one bootstrap sample $(b=1)$ means randomly sampling $\mathbf{N}$ times the temperature data set of size $\mathbf{N}$ for the particular fish species. 


\subsection{Extreme temperature uncertainty estimation}

\subsubsection{Method of moments}

A measure of the variability of the estimated extreme temperature is the standard error of estimate. The standard error of estimate is defined (Kite, 1988) as

$$
S E_{M}=\delta \sqrt{\frac{\mu_{2}}{N}}
$$

where $\mu_{2}$ is the second statistical moment, and $\delta$ is tabulated for the different percentile levels and different probability distributions (Kite, 1988).

\subsubsection{Bootstrap method}

The bootstrap method is a nonparametric computational method for the standard error of a data-based prediction (Efron and Gong, 1983). The method was applied to the standard error of the 95th percentile estimator. For each fish species a bootstrap sample was drawn 1000 times and the standard error was computed as

$$
S E_{B}=\left[\sum_{b=1}^{B} \frac{\left(\hat{T}_{95}^{b}-\hat{T}_{95}^{B}\right)^{2}}{B-1}\right]^{\frac{1}{2}}
$$

\subsubsection{Residual method}

A third method to estimate standard error of the of the 95th percentile FTDMS value uses the temperature residuals above the 95th percentile value in all 52 weeks in a year. The graphical illustration of the residuals is given for walleye in Fig. 1c. The method considers residual temperature values above the 95th percentile for all 52 weeks of the entire year, but could be applied to a smaller number of weeks also. The standard error of estimate for the 95th percentiles is defined as 


$$
S E_{r}=\left[\sum_{i=1}^{n} \frac{\left(T_{i}-\hat{T}_{95 i}\right)^{2}}{N-1}\right]^{\frac{1}{2}} \text { for } T_{i}>\hat{T}_{95 i}
$$

where the $\hat{T}_{95 i}$ is the estimated 95th percentile for the particular week, $T_{i}$ is the temperature above the 95 th percentile, and $\mathrm{SE}_{\mathrm{r}}$ is the yearly standard error of estimate for the 95th percentiles.

\subsubsection{Confidence interval}

Once the standard error of the estimate is computed it is often desirable to estimate the confidence interval for the temperature percentile in question. In order to proceed, the assumption is made that the distribution of the T-percentile is normal so that the confidence interval is given by

$$
C I=T_{\mathscr{F}} \pm t S E
$$

where $t$ is the standard normal deviate for the desired confidence level $(t=1.96$ for the $95 \%$ cumulative probability), and $T_{\%}$ is the temperature estimate for the required cumulative probability. 


\section{Results}

\subsection{Extreme temperature computation}

\subsubsection{Maximum 95th percentile weekly temperatures}

Maximum 95th percentile temperature estimates for the week when the highest 95th percentile temperature occurred are given in Table 1 (under the column "Maximum 95\% Weekly Temperature"). Estimated UEHT were lower than the upper temperature tolerance limit (UTTL) from the laboratory experiments. Average differences between weekly upper extreme habitat temperatures and UTTL temperatures were $2.1,2.0$, and $4.5^{\circ} \mathrm{C}$ for the cold-, cool-, and warmwater fish species, respectively. The greater difference for the warmwater fishes is believed due to the fact that the data for some species in this guild do not include higher temperatures from sites at the extreme southern limits of their distribution, south of the U.S. border (Mexico), where such fishes can still exist. Data collection does not extend south of the U.S. border.

\subsubsection{Probability distributions fitted to temperatures above maximum growth temperature}

\section{(Parametric method)}

The parametric procedure was applied as an alternative second method for the extreme temperature estimation. The "samples" contained all temperatures above the maximum growth temperature for the particular fish species. Fitted and "observed" cumulative probability distributions of these data are given in Figures $2 a, 2 b$, and $2 c$. Good agreement between the observed and fitted temperatures is evident. Quantile plots for the observed and fitted temperatures are given in Figures 3a, 3b, and 3c. Qualitative measures of agreement between the observed and fitted temperature (Eq. 4), are given in Table 1 under the column "Goodness-of-Fit". In most cases the "Goodness of Fit" had an $\mathrm{r}^{2}$ value above 0.95 . This implies that $95 \%$ of the observed temperature variability was explained by the fitted probability distribution. For brown bulhead, channel catfish, freshwater drum, and gizzard shad, were lower agreement values calculated. These poorer agreements are believed to be mainly due to the temperature "extremes" above the probability distributions (Figures 3a,3b, and 3c). It is noteworthy that the extremes were always above the estimated maximum 95th percentile weekly temperatures. This is one more justification for selecting the 95th percentile rather than the very highest temperature observed as a lethal temperature 

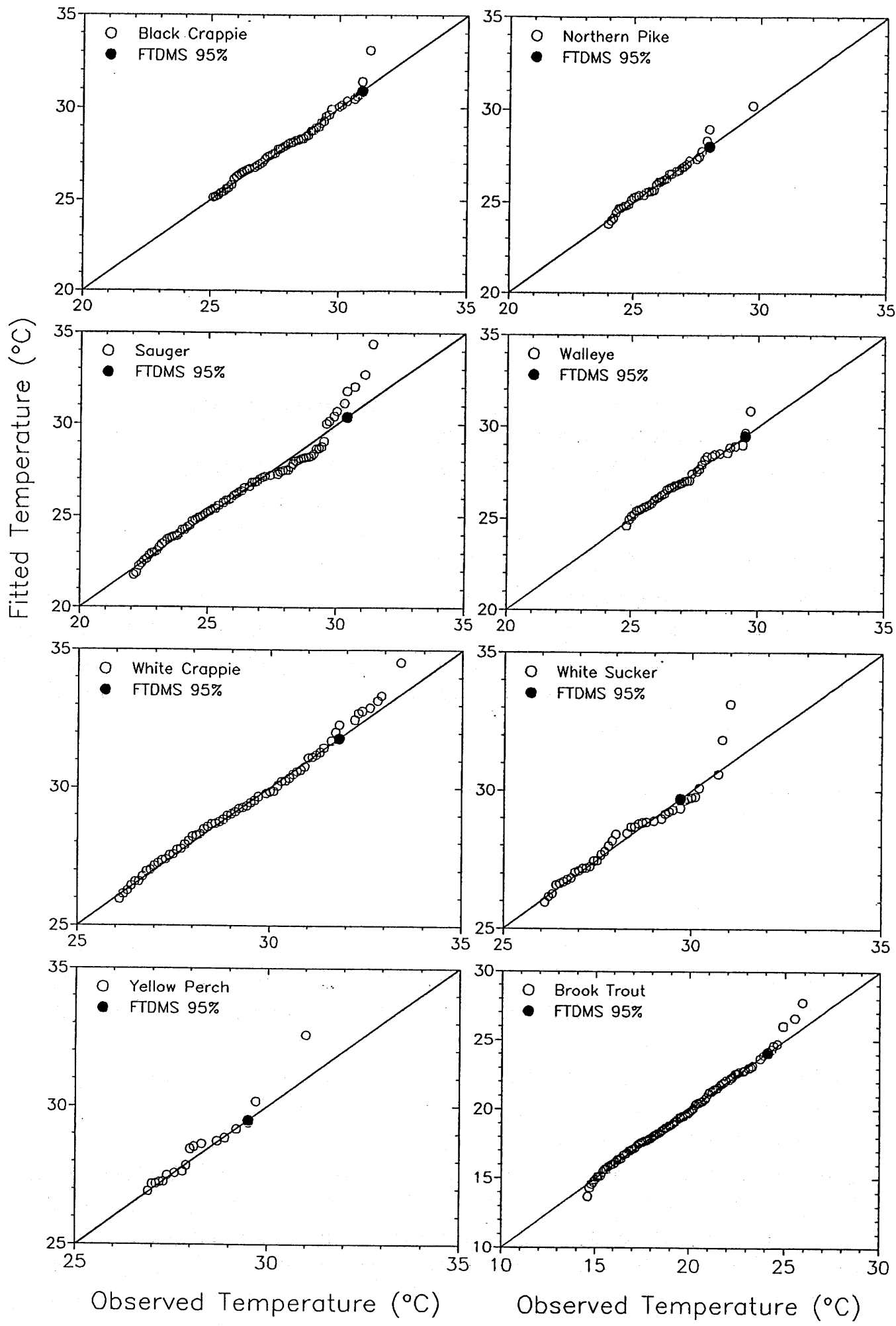

Fig.3a Quantile-quantile plots for distributions fitted by method of moments to fish/temperature pairs in the FTDMS. Horizontal axes are observed and the vertical axes are fitted temperatures. The solid line would be a perfect fit. 

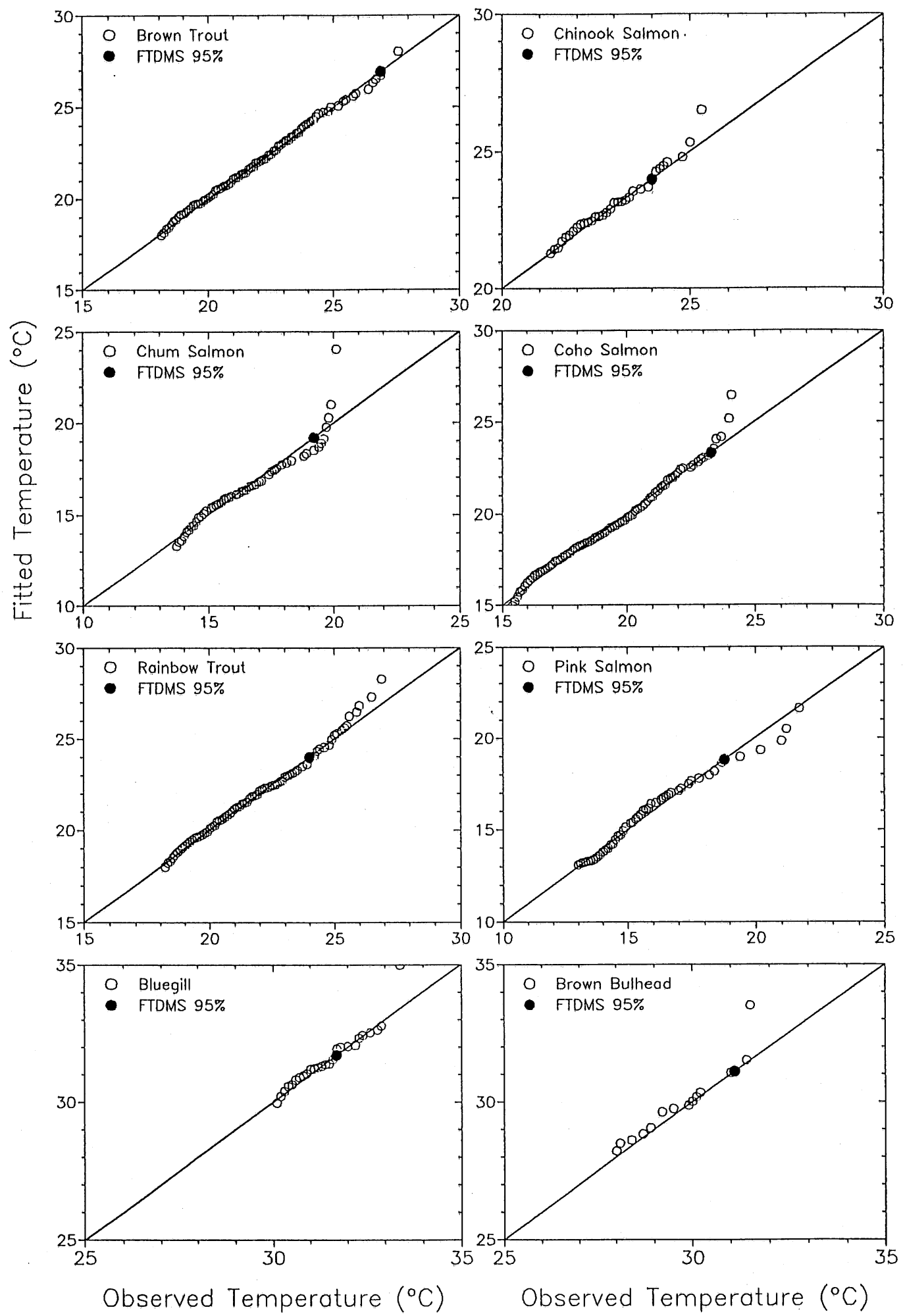

Fig.3b Quantile-quantile plots for distributions fitted by method of moments to fish/temperature pairs in the FTDMS. Horizontal axes are observed and the vertical axes are fitted temperatures. The solid line would be a perfect fit. 

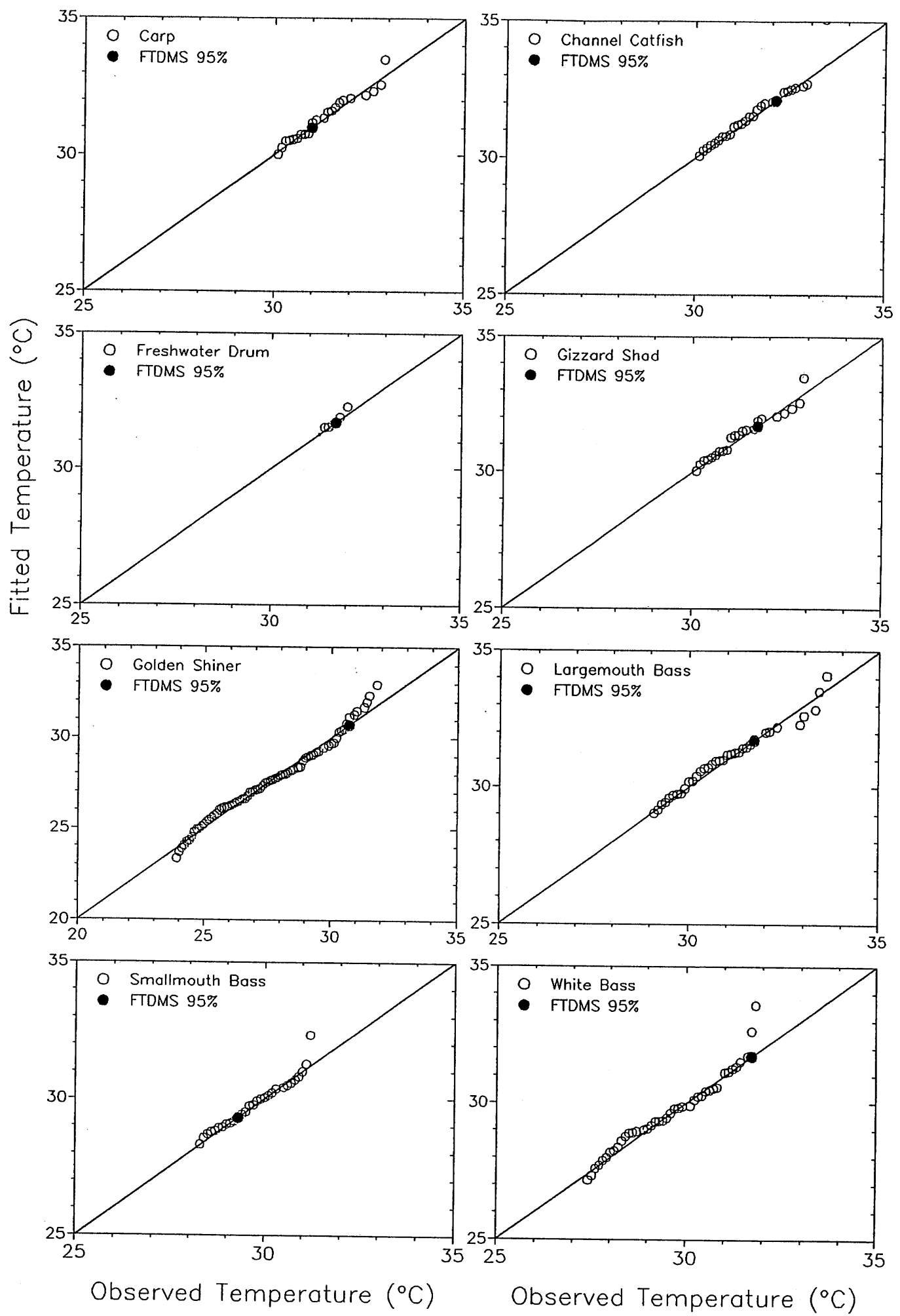

Fig.3c Quantile-quantile plots for distributions fitted by method of moments to fish/temperature pairs in the FTDMS. Horizontal axes are observed and the vertical axes are fitted temperatures. The solid line would be a perfect fit. 
Table $1 \quad$ Fish species/temperature statistics.

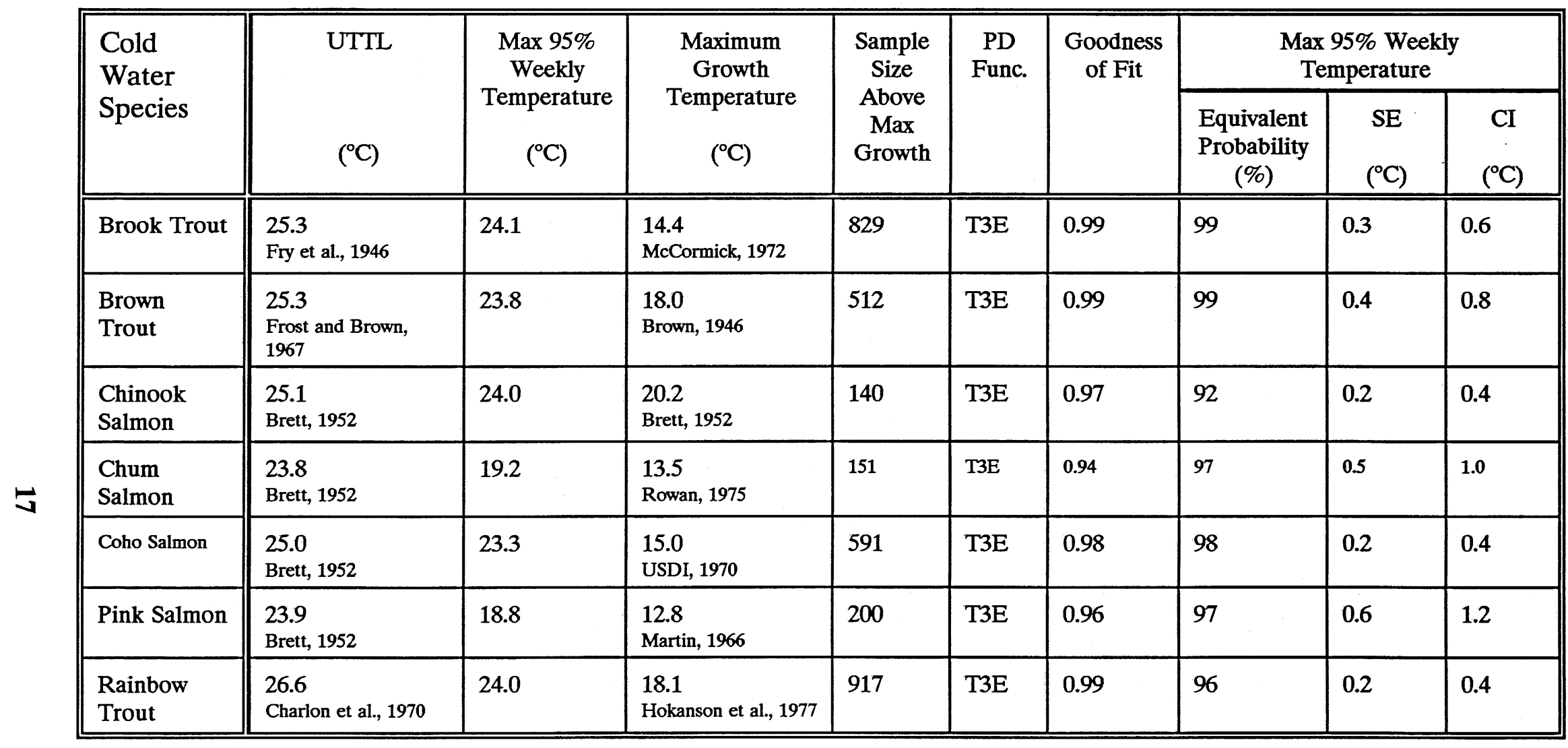

UTTL - Upper Temperature Tolerance Limit

PD - Probability Distribution

T3E - Type III extremal distribution

LN3 - Three-parameter lognormal distribution

SE - Standard Error

CI - Confidence Interval 
Table 1 (cont)

\begin{tabular}{|c|c|c|c|c|c|c|c|c|c|}
\hline \multirow{2}{*}{$\begin{array}{l}\text { Cool } \\
\text { Water } \\
\text { Species }\end{array}$} & \multirow{2}{*}{$\begin{array}{l}\text { UTTL } \\
\left({ }^{\circ} \mathrm{C}\right)\end{array}$} & \multirow{2}{*}{$\begin{array}{c}\text { Max } 95 \% \\
\text { Weekly } \\
\text { Temperature } \\
\left({ }^{\circ} \mathrm{C}\right)\end{array}$} & \multirow{2}{*}{$\begin{array}{c}\text { Maximum } \\
\text { Growth } \\
\text { Temperature } \\
\left({ }^{\circ} \mathrm{C}\right)\end{array}$} & \multirow{2}{*}{$\begin{array}{l}\text { Sample Size } \\
\text { Above Max } \\
\text { Growth }\end{array}$} & \multirow[t]{2}{*}{$\begin{array}{l}\text { PD } \\
\text { Func. }\end{array}$} & \multirow[t]{2}{*}{$\begin{array}{l}\text { Goodness } \\
\text { of Fit }\end{array}$} & \multicolumn{3}{|c|}{$\begin{array}{c}\text { Max } 95 \% \text { Weekly } \\
\text { Temperature }\end{array}$} \\
\hline & & & & & & & $\begin{array}{c}\text { Equivalent } \\
\text { Probability } \\
(\%)\end{array}$ & $\begin{array}{l}\text { SE } \\
\left({ }^{\circ} \mathrm{C}\right)\end{array}$ & $\begin{array}{l}\mathrm{CI} \\
\left({ }^{\circ} \mathrm{C}\right)\end{array}$ \\
\hline $\begin{array}{l}\text { Black } \\
\text { Crappie }\end{array}$ & $\begin{array}{l}32.5 \\
\text { Hokanson and Kleiner, } \\
1981\end{array}$ & 30.9 & $\begin{array}{l}28.3 \\
\text { Neill and Magnuson, } \\
1973\end{array}$ & 344 & T3E & 0.98 & 99 & 0.3 & 0.6 \\
\hline $\begin{array}{l}\text { Northern } \\
\text { Pike }\end{array}$ & $\begin{array}{l}28.4 \\
\text { Hokanson et al., } 1973\end{array}$ & 28.0 & $\begin{array}{l}23.9 \\
\text { Hokanson et al., } 1973\end{array}$ & 198 & T3E & 0.97 & 98 & 0.3 & 0.6 \\
\hline Sauger & $\begin{array}{l}30.4 \\
\text { Smith and Koenst, } \\
1975\end{array}$ & 30.4 & $\begin{array}{l}22.0 \\
\text { Smith and Koenst, } \\
1975\end{array}$ & 548 & T3E & 0.98 & 98 & 0.3 & 0.6 \\
\hline Walleye & $\begin{array}{l}34.1 \\
\text { Hokanson and Koenst, } \\
1986 \\
\end{array}$ & 29.5 & $\begin{array}{l}24.7 \\
\text { Hokanson and Koenst, } \\
1986\end{array}$ & 292 & T3E & 0.98 & 99 & 0.2 & 0.4 \\
\hline $\begin{array}{l}\text { White } \\
\text { Crappie }\end{array}$ & $\begin{array}{l}32.8 \\
\text { Peterson et al., } 1974\end{array}$ & 31.8 & $\begin{array}{l}28.5 \\
\text { Gammon, } 1973\end{array}$ & 717 & T3E & 0.99 & 97 & 0.2 & 0.4 \\
\hline $\begin{array}{l}\text { White } \\
\text { Sucker }\end{array}$ & $\begin{array}{l}32.4 \\
\text { Koenst, } 1982\end{array}$ & 29.7 & $\begin{array}{l}26.0 \\
\text { McCormick et al., } 1977\end{array}$ & 272 & T3E & 0.95 & 92 & 0.2 & 0.4 \\
\hline $\begin{array}{l}\text { Yellow } \\
\text { Perch }\end{array}$ & $\begin{array}{l}33.0 \\
\text { McCormick, } 1976\end{array}$ & 29.5 & $\begin{array}{l}26.8 \\
\text { McCormick, } 1976\end{array}$ & 54 & LN3 & 0.90 & 96 & 0.4 & 0.8 \\
\hline
\end{tabular}

UTTL - Upper Temperature Tolerance Limit

PD - Probability Distribution

SE - Standard Error

CI - Confidence Interval 
Table 1 (cont)

\begin{tabular}{|c|c|c|c|c|c|c|c|c|c|}
\hline \multirow[t]{2}{*}{$\begin{array}{l}\text { Warm Water } \\
\text { Species }\end{array}$} & \multirow[t]{2}{*}{ UTTL } & \multirow{2}{*}{$\begin{array}{c}\text { Max } \\
95 \% \\
\text { Weekly } \\
\text { Temp. } \\
\left({ }^{\circ} \mathrm{C}\right)\end{array}$} & \multirow{2}{*}{$\begin{array}{l}\text { Maximum } \\
\text { Growth } \\
\text { Temp. } \\
\left({ }^{\circ} \mathrm{C}\right)\end{array}$} & \multirow{2}{*}{$\begin{array}{l}\text { Sample } \\
\text { Size } \\
\text { Above } \\
\text { Max } \\
\text { Growth }\end{array}$} & \multirow[t]{2}{*}{$\begin{array}{l}\text { PD } \\
\text { Func. }\end{array}$} & \multirow[t]{2}{*}{$\begin{array}{l}\text { Goodness } \\
\text { of Fit }\end{array}$} & \multicolumn{3}{|c|}{$\begin{array}{l}\text { Max } 95 \% \text { Weekly } \\
\text { Temperature }\end{array}$} \\
\hline & & & & & & & $\begin{array}{l}\text { Equiv. } \\
\text { Probab. } \\
\text { (\%) }\end{array}$ & $\begin{array}{l}\mathrm{SE} \\
\left({ }^{\circ} \mathrm{C}\right)\end{array}$ & $\begin{array}{l}\mathrm{CI} \\
\left({ }^{\circ} \mathrm{C}\right)\end{array}$ \\
\hline Bluegill & $\begin{array}{l}37.3 \\
\text { Banner and Van Arman, } 1973\end{array}$ & 31.7 & $\begin{array}{l}30.0 \\
\text { Lemke, } 1977\end{array}$ & 222 & T3E & 0.94 & 82 & 0.1 & 0.2 \\
\hline $\begin{array}{l}\text { Brown } \\
\text { Bullhead }\end{array}$ & $\begin{array}{l}37.5 \\
\text { Brett, } 1944\end{array}$ & 31.1 & $\begin{array}{l}27.8 \\
\text { Keast, } 1985\end{array}$ & 26 & T3E & 0.90 & 93 & 0.4 & 0.8 \\
\hline Carp & $\begin{array}{l}36.0 \\
\text { Meuwis and Heuts, } 1957\end{array}$ & 31.0 & $\begin{array}{l}30.0 \\
\text { Tatarko, } 1966\end{array}$ & 112 & T3E & 0.93 & 66 & 0.1 & 0.2 \\
\hline $\begin{array}{l}\text { Channel } \\
\text { Catfish }\end{array}$ & $\begin{array}{l}37.8 \\
\text { Allen and Strawn, } 1968\end{array}$ & 32.1 & $\begin{array}{l}30.0 \\
\text { Andrews and Stickney, } 1972\end{array}$ & 199 & T3E & 0.80 & 90 & 0.1 & 0.2 \\
\hline $\begin{array}{l}\text { Freshwater } \\
\text { Drum }\end{array}$ & $\begin{array}{l}32.8 \\
\text { Cvancara et al., } 1977\end{array}$ & 31.7 & $\begin{array}{l}31.3 \\
\text { Reuter and Herendorf, } 1976\end{array}$ & 23 & LN3 & 0.80 & 71 & 0.1 & 0.2 \\
\hline $\begin{array}{l}\text { Gizzard } \\
\text { Shad }\end{array}$ & $\begin{array}{l}36.5 \\
\text { Hart, } 1952\end{array}$ & 31.7 & $\begin{array}{l}30.0 \\
\text { Gammon, } 1971\end{array}$ & 130 & T3E & 0.92 & 93 & 0.1 & 0.2 \\
\hline $\begin{array}{l}\text { Golden } \\
\text { Shiner }\end{array}$ & $\begin{array}{l}34.7 \\
\text { Hart, } 1952\end{array}$ & 30.7 & $\begin{array}{l}23.8 \\
\text { Cincotta and Stauffer, } 1984\end{array}$ & 395 & T3E & 0.98 & 97 & 0.3 & 0.6 \\
\hline $\begin{array}{l}\text { Largemouth } \\
\text { Bass }\end{array}$ & $\begin{array}{l}36.4 \\
\text { Hart, } 1952\end{array}$ & 31.7 & $\begin{array}{l}29.0 \\
\text { McCormick and Wegner, } \\
1981\end{array}$ & 307 & T3E & 0.94 & 87 & 0.1 & 0.2 \\
\hline $\begin{array}{l}\text { Smallmouth } \\
\text { Bass }\end{array}$ & $\begin{array}{l}35.0 \\
\text { Cherry et al., } 1977\end{array}$ & 29.3 & $\begin{array}{l}28.2 \\
\text { Horning and Pearson, } 1973\end{array}$ & 88 & T3E & 0.95 & 56 & 0.1 & 0.2 \\
\hline White Bass & $\begin{array}{l}33.5 \\
\text { Cvancera et al., } 1977\end{array}$ & 31.7 & $\begin{array}{l}27.3 \\
\text { McCormick, personal comm. }\end{array}$ & 237 & T3E & 0.96 & 97 & 0.1 & 0.2 \\
\hline
\end{tabular}


(maximum 95th percentile weekly temperatures are also shown in Figs 3a, 3b, and $3 c$ to illustrate how far below the very highest observed temperatures they may be).

Cumulative probabilities above maximum growth temperature equivalent to the maximum 95th percentile temperature estimates were also determined and are given in Table 1 under the heading "Equivalent Probability". Cold- and coolwater fishes had equivalent cumulative probabilities from $92 \%$ to $99 \%$. Warmwater fishes had equivalent cumulative probabilities from $56 \%$ (smallmouth bass) to $97 \%$ (white bass). A low cumulative percentile indicates that many high temperature estimates were ignored in the maximum 95 th percentile weekly temperature estimate.

\subsubsection{5th and 99th percentile temperatures above maximum growth temperature}

The parametric method and the bootstrap method were used as prediction tools for the 95th and 99th percentiles of temperatures above the maximum growth. Estimated temperatures are given in Table 2 under the heading "95\%" or "99\%". The temperatures estimated by the bootstrap and the parametric method are very close. That is an indication that the fitted theoretical distributions adequately describe the temperature samples.

\subsection{Uncertainty of extreme temperature computation}

\subsubsection{Method of moments}

Standard errors of estimated maximum 95th percentiles weekly temperatures are given in Table 1 . These values were obtained by the method of moments. An average standard error was $0.3,0.3$, and $0.1^{\circ} \mathrm{C}$ for the cold-, cool-, and warmwater fishes, respectively. With these standard errors the confidence intervals (95\%) for the estimated maximum 95th percentile weekly temperatures were obtained and are given in Table 1 under the heading "Confidence Interval (CI)".

The uncertainty of estimated extreme values (see e.g. Figs 3a,3b, and $3 c$ ) would be expected to increase towards the higher temperatures. To test this increase, standard errors of extreme water temperatures at cumulative probabilities of occurrence increasing from 50 percentile to 99 percentile were also estimated by the method of moments. The results for different fish species and different cumulative probability levels are summarized in Fig. 4. Indeed the standard error increases less than $0.3^{\circ} \mathrm{C}$ at $50 \%$ to up to $1^{\circ} \mathrm{C}$ at $99 \%$, with considerable variation among species. The excedance level, which is also shown in Fig 4 is defined as $100-\alpha$, where $\alpha$ is the cumulative probability. 
Table $295 \%$ and $99 \%$ temperatures and standard errors of these water temperatures as determined by the bootstrap method and by the fitted cumulative probability function (parametric) method to temperature data (samples) above maximum growth temperature.

\begin{tabular}{||l||l|l|l|l|l|l|l|l||}
\hline \hline $\begin{array}{l}\text { Cold } \\
\text { Water } \\
\text { Species }\end{array}$ & \multicolumn{5}{|c|}{ Bootstrap } & \multicolumn{5}{c||}{ Parametric } \\
\cline { 2 - 10 } & $\begin{array}{l}95 \% \\
\left.{ }^{\circ} \mathrm{C}\right)\end{array}$ & $\begin{array}{l}\mathrm{SE} \\
\left({ }^{\circ} \mathrm{C}\right)\end{array}$ & $\begin{array}{l}99 \% \\
\left({ }^{\circ} \mathrm{C}\right)\end{array}$ & $\begin{array}{l}\mathrm{SE} \\
\left({ }^{\circ} \mathrm{C}\right)\end{array}$ & $\begin{array}{l}95 \% \\
\left({ }^{\circ} \mathrm{C}\right)\end{array}$ & $\begin{array}{l}\text { SE } \\
\left({ }^{\circ} \mathrm{C}\right)\end{array}$ & $\begin{array}{l}99 \% \\
\left({ }^{\circ} \mathrm{C}\right)\end{array}$ & $\begin{array}{l}\text { SE } \\
\left({ }^{\circ} \mathrm{C}\right)\end{array}$ \\
\hline \hline $\begin{array}{l}\text { Brook } \\
\text { Trout }\end{array}$ & 22.0 & 0.2 & 24.3 & 0.3 & 22.1 & 0.2 & 24.4 & 0.3 \\
\hline $\begin{array}{l}\text { Brown } \\
\text { Trout }\end{array}$ & 24.6 & 0.4 & 27.0 & 0.5 & 24.7 & 0.2 & 27.0 & 0.4 \\
\hline $\begin{array}{l}\text { Chinook } \\
\text { Salmon }\end{array}$ & 24.1 & 0.1 & 24.8 & 0.3 & 24.3 & 0.2 & 25.2 & 0.3 \\
\hline $\begin{array}{l}\text { Chum } \\
\text { Salmon }\end{array}$ & 19.1 & 0.5 & 19.8 & 0.2 & 18.6 & 0.4 & 20.7 & 0.8 \\
\hline $\begin{array}{l}\text { Coho } \\
\text { Salmon }\end{array}$ & 21.9 & 0.2 & 23.5 & 0.2 & 22.1 & 0.2 & 23.9 & 0.3 \\
\hline $\begin{array}{l}\text { Pink } \\
\text { Salmon }\end{array}$ & 17.6 & 0.7 & 21.0 & 0.9 & 17.8 & 0.4 & 20.6 & 1.0 \\
\hline $\begin{array}{l}\text { Rainbow } \\
\text { Trout }\end{array}$ & 23.9 & 0.1 & 25.1 & 0.2 & 23.6 & 0.1 & 25.4 & 0.3 \\
\hline
\end{tabular}

\begin{tabular}{||l||l|l|l|l|l|l|l|l||}
\hline \hline $\begin{array}{l}\text { Cool } \\
\text { Water } \\
\text { Species }\end{array}$ & \multicolumn{5}{|c|}{ Bootstrap } & \multicolumn{5}{c||}{ Parametric } \\
\cline { 2 - 10 } & $95 \%$ \\
$\left({ }^{\circ} \mathrm{C}\right)$ & $\begin{array}{l}\mathrm{SE} \\
\left({ }^{\circ} \mathrm{C}\right)\end{array}$ & $\begin{array}{l}99 \% \\
\left({ }^{\circ} \mathrm{C}\right)\end{array}$ & $\begin{array}{l}\text { SE } \\
\left({ }^{\circ} \mathrm{C}\right)\end{array}$ & $\begin{array}{l}95 \% \\
\left({ }^{\circ} \mathrm{C}\right)\end{array}$ & $\begin{array}{l}\text { SE } \\
\left({ }^{\circ} \mathrm{C}\right)\end{array}$ & $\begin{array}{l}99 \% \\
\left({ }^{\circ} \mathrm{C}\right)\end{array}$ & $\begin{array}{l}\text { SE } \\
\left({ }^{\circ} \mathrm{C}\right)\end{array}$ \\
\hline \hline $\begin{array}{l}\text { Black } \\
\text { Crappie }\end{array}$ & 29.6 & 0.2 & 30.8 & 0.2 & 29.7 & 0.2 & 31.0 & 0.3 \\
\hline $\begin{array}{l}\text { Northern } \\
\text { Pike }\end{array}$ & 27.6 & 0.2 & 28.1 & 0.5 & 27.5 & 0.2 & 28.6 & 0.3 \\
\hline Sauger & 29.4 & 0.1 & 30.2 & 0.2 & 28.9 & 0.2 & 31.0 & 0.4 \\
\hline Walleye & 28.5 & 0.4 & 29.6 & 0.1 & 28.6 & 0.1 & 29.5 & 0.2 \\
\hline $\begin{array}{l}\text { White } \\
\text { Crappie }\end{array}$ & 31.2 & 0.1 & 32.1 & 0.3 & 31.2 & 0.1 & 32.6 & 0.2 \\
\hline $\begin{array}{l}\text { White } \\
\text { Sucker }\end{array}$ & 30.3 & 0.3 & 30.8 & 0.1 & 30.1 & 0.2 & 31.3 & 0.3 \\
\hline $\begin{array}{l}\text { Yellow } \\
\text { Perch }\end{array}$ & 29.4 & 0.4 & 30.0 & 0.6 & 29.4 & 0.4 & 30.6 & 0.9 \\
\hline
\end{tabular}


Table 2 (cont)

\begin{tabular}{||l||l|l|l|l|l|l|l|l||}
\hline $\begin{array}{l}\text { Warm } \\
\text { Water } \\
\text { Species }\end{array}$ & \multicolumn{7}{|c|}{ Bootstrap } & \multicolumn{3}{c||}{ Parametric } \\
\cline { 2 - 10 } & $\begin{array}{l}95 \% \\
\left({ }^{\circ} \mathrm{C}\right)\end{array}$ & $\begin{array}{l}\text { SE } \\
\left({ }^{\circ} \mathrm{C}\right)\end{array}$ & $\begin{array}{l}99 \% \\
\left({ }^{\circ} \mathrm{C}\right)\end{array}$ & $\begin{array}{l}\text { SE } \\
\left({ }^{\circ} \mathrm{C}\right)\end{array}$ & $\begin{array}{l}95 \% \\
\left({ }^{\circ} \mathrm{C}\right)\end{array}$ & $\begin{array}{l}\text { SE } \\
\left({ }^{\circ} \mathrm{C}\right)\end{array}$ & $\begin{array}{l}99 \% \\
\left({ }^{\circ} \mathrm{C}\right)\end{array}$ & $\begin{array}{l}\text { SE } \\
\left({ }^{\circ} \mathrm{C}\right)\end{array}$ \\
\hline \hline Bluegill & 32.6 & 0.3 & 33.4 & 0.1 & 32.6 & 0.2 & 33.5 & 0.3 \\
\hline $\begin{array}{l}\text { Brown } \\
\text { Bullhead }\end{array}$ & 31.1 & 0.4 & 31.2 & 0.3 & 31.3 & 0.4 & 32.2 & 0.7 \\
\hline Carp & 31.8 & 0.2 & 32.5 & 0.3 & 31.9 & 0.1 & 32.6 & 0.2 \\
\hline $\begin{array}{l}\text { Channel } \\
\text { Catfish }\end{array}$ & 32.7 & 0.4 & 33.4 & 0.1 & 32.6 & 0.2 & 33.5 & 0.3 \\
\hline $\begin{array}{l}\text { Freshwater } \\
\text { Drum }\end{array}$ & 31.8 & 0.1 & 31.9 & 0.1 & 31.9 & 0.1 & 32.0 & 0.1 \\
\hline $\begin{array}{l}\text { Gizzard } \\
\text { Shad }\end{array}$ & 31.8 & 0.2 & 32.5 & 0.3 & 31.8 & 0.1 & 32.5 & 0.2 \\
\hline $\begin{array}{l}\text { Golden } \\
\text { Shiner }\end{array}$ & 30.2 & 0.1 & 31.0 & 0.3 & 30.0 & 0.2 & 31.7 & 0.3 \\
\hline $\begin{array}{l}\text { Largemouth } \\
\text { Bass }\end{array}$ & 33.1 & 0.2 & 33.6 & 0.1 & 32.7 & 0.3 & 34.1 & 0.4 \\
\hline $\begin{array}{l}\text { Smallmouth } \\
\text { Bass }\end{array}$ & 31.0 & 0.1 & 30.6 & 0.2 & 30.7 & 0.2 & 31.3 & 0.3 \\
\hline White Bass & 31.2 & 0.2 & 31.7 & 0.1 & 31.3 & 0.2 & 32.2 & 0.2 \\
\hline
\end{tabular}



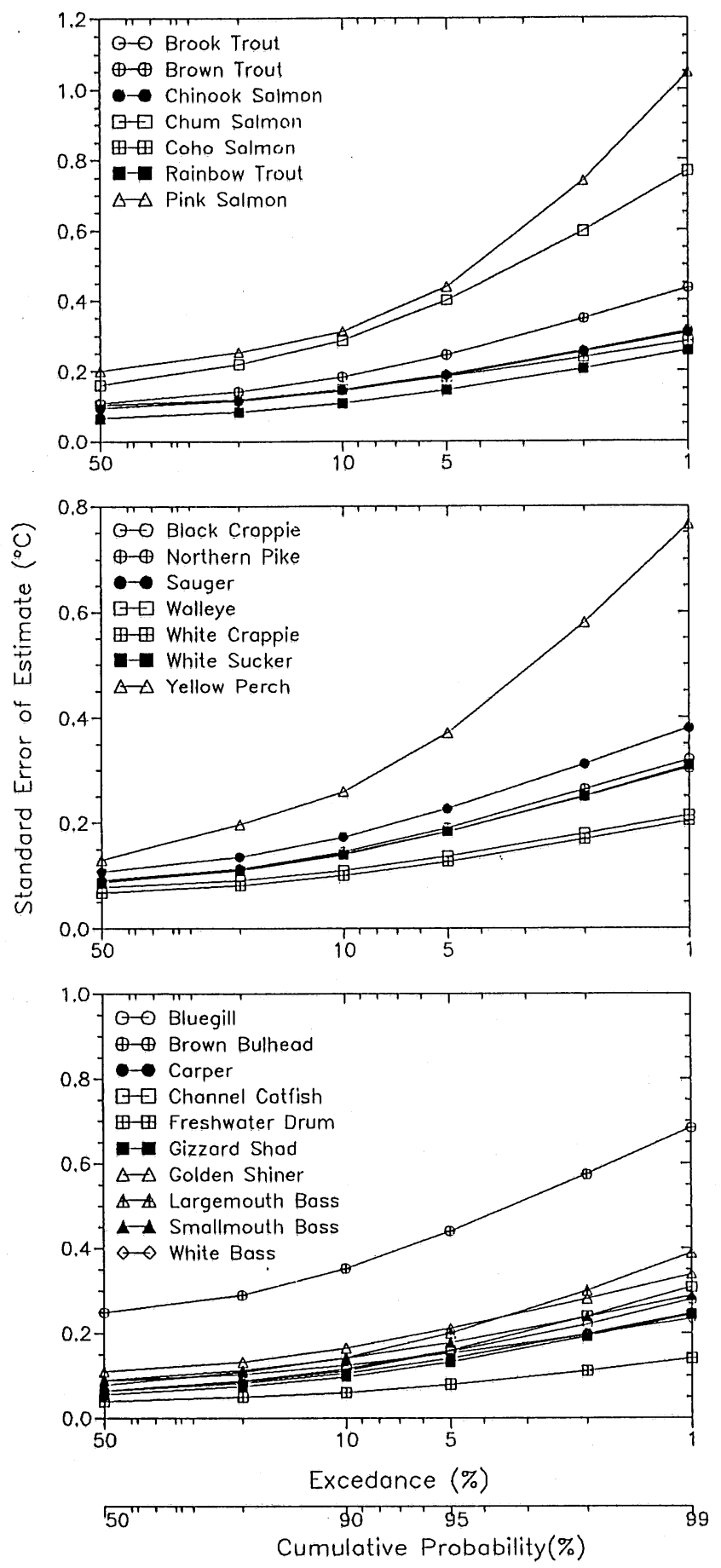

Fig. 4 Standard errors of temperature estimates for different cumulative probabilities or excedance levels above maximum growth temperature. 


\subsubsection{Bootstrap method}

Uncertainty was also computed by applying the bootstrap method to the "samples". For the 95th and 99th percentile cumulative probabilities the standard errors are given in Table 2 under the heading "Bootstrap". The method of moments was applied to the same sample for comparison. The estimated standard errors are given in Table 2 under the heading "Parametric". It is interesting to note that the bootstrap estimates are in some cases (walleye, white sucker, chum salmon, bluegill, brown bullhead, channel catfish, largemouth bass, white bass) higher for the 95th percentile than for the 99th percentile. This unexplainable trend is considered to be a deficiency of the bootstrap method in comparison to the parametric estimates. Overall the two methods give very similar results for the same cumulative probability levels.

\subsubsection{Residual method}

Prior to the uncertainty analysis by the method of moments and the bootstrap method, a residual method had been applied. It used as a basic data set the residual temperatures above the maximum weekly 95 th percentile weekly temperatures (see Fig. 1c, and section 4.3) for all weeks of the year. The method makes use of data from all seasons of the year. Standard errors of estimated maximum 95th percentile weekly temperatures obtained by residual method are given in Table 3. The estimated standard error therefore reflects an annual average of uncertainty for all 52 weekly 95 percentile temperature values, rather than the maximum value of the year. To obtain an uncertainty estimate for the warmest season, characterized empirically as a five week average around the week with the maximum 95th percentile weekly temperature was also computed. These latter values are on the average lower than the annual average error, but still higher than the standard errors in Tables 1 and 2. 
Table 3 Standard errors of Maximum $95 \%$ weekly water temperatures as determined by analysis of residuals above maximum $95 \%$ weekly values.

\begin{tabular}{||l|l||l|l||l|l||}
\hline $\begin{array}{l}\text { Coldwater } \\
\text { Species }\end{array}$ & \multicolumn{1}{|c|}{$\mathrm{SE}\left({ }^{\circ} \mathrm{C}\right)$} & $\begin{array}{l}\text { Coolwater } \\
\text { Species }\end{array}$ & SE $\left({ }^{\circ} \mathrm{C}\right)$ & $\begin{array}{l}\text { Warmwater } \\
\text { Species }\end{array}$ & SE $\left({ }^{\circ} \mathrm{C}\right)$ \\
\hline \hline Brook Trout & 1.3 & Black Crappie & 1.5 & Bluegill & 1.1 \\
\hline Brown Trout & 1.0 & Northern Pike & 0.5 & Brown Bullhead & 1.5 \\
\hline Chinook Salmon & 0.9 & Sauger & 1.2 & Carp & 2.0 \\
\hline Chum Salmon & 0.8 & Walleye & 0.7 & Channel Catfish & 1.4 \\
\hline Coho Salmon & 1.3 & White Crappie & 0.8 & Freshwater Drum & 1.6 \\
\hline Pink Salmon & 1.3 & White Sucker & 2.0 & Gizzard Shad & 0.7 \\
\hline Rainbow Trout & 1.5 & Yellow Perch & 1.7 & Golden Shiner & 1.0 \\
\hline \multirow{2}{*}{ SE - Standard Error } & & Largemouth Bass & 1.6 \\
\hline & & & Smallmouth Bass & 1.6 \\
\hline
\end{tabular}




\section{Discussion}

Upper extreme habitat temperatures are potentially useful in aquaculture/fish pond management, for setting of water temperature standards, for specification of cooling water effluent mixing zones, and in climate effect studies. Herein, upper extreme habitat water temperature values and their uncertainties are determined by several statistical methods from a large field database (Fish and Temperature Database Matching System, FTDMS, Eaton et al. 1995). The results place previous estimates of upper extreme habitat temperatures in a broader statistical context, and provide confidence intervals for these estimates. The reader should be aware that the FTDMS database is continually growing and therefore that this paper presents options for summarizing the data and not the final values for maximum habitat temperatures.

One expression of the upper extreme habitat temperatures was chosen to be the 95th percentile of weekly mean temperatures occurring in the week with the highest weekly mean temperature for each fish species. Herein the data are reduced to only those temperature values which lie above the maximum (optimum) growth temperature (threshold) of a fish species. Above this threshold water temperature affects fish growth adversely. The data above the maximum growth temperature are analyzed by two different methods: (1) a parametric method, which fits a theoretical probability distribution to the data, and (2) a non-parametric (bootstrap) method. The type III extremal distribution or the three-parameter lognormal distribution provide a good fit to the data (Figs. 2 and 3).

Extreme high temperature values and their uncertainties are determined by both the parametric and the bootstrap method and give similar results. Examples of the 95\% and 99\% cumulative probability level are given in Table 2 for 24 fish species. The increase of uncertainty with cumulative probability is illustrated in Fig. 4. Standard error ranges from less than $0.3^{\circ} \mathrm{C}$ at $50 \%$ to more than $1^{\circ} \mathrm{C}$ at $99 \%$, with a strong dependence on the species of fish. The higher uncertainties in lethal temperature estimates as measured by the high standard error of estimate in Fig. 4 for yellow perch, rainbow trout, pink salmon, and brown bullhead, are caused by either the small sample size (54 temperature data points above maximum growth for yellow perch, and 26 for brown bullhead, see Table 1) and/or unusually poor fit of the frequency distributions in the high temperature range as illustrated in Figs. 2 and 3. 
The uncertainty of the maximum 95th percentile weekly temperature value has a standard error which has been estimated, by the method of moments from the parametric (fitted) distributions, to be between 0.2 to $0.6^{\circ} \mathrm{C}$ for coldwater species, 0.2 to $0.4^{\circ} \mathrm{C}$ for coolwater fishes, and from 0.1 to $0.4^{\circ} \mathrm{C}$ for warmwater fishes (Table 1). The database for the warmwater fishes does not, however, extend far enough south to include the high temperature extremes for some species.

In conclusion the significance of this study lies in the following main points:

(a) Known methods of extreme value analysis used in other fields (e.g. flood frequency analysis) have been applied to broaden the usefulness of a large fish/temperature field database.

(b) Extreme values for 24 fish species were found to follow two extreme value frequency distributions. They are the type III extremal and the threeparameter lognormal distributions. Therefore smaller datasets can be used to estimate more reliably upper extreme habitat temperatures.

(c) By providing a theoretically well-founded methodology, the uncertainty of the upper extreme habitat temperatures has been established more exactly. 


\section{Acknowledgements}

We are grateful to the U.S. Environmental Protection Agency, Office of Program Planning and Evaluation, Washington, D.C., and Environmental Research Laboratory-Duluth, Minnesota, for support of this study. Brian Goodno, Dan O'Brien, and Ken Hokanson provided lake and fish/temperature data bases, without which this work could not have been done. 


\section{References}

Allen, K.O. and K. Strawn, 1968. Heat tolerance of channel catfish Itcalurus punctatus, Proc. Ann. Conf. Southeast Assoc. Game Fish Comm., 21: 399-410.

Andrews, J.W. and R.R. Stickney, 1972. Interactions of feeding rates and environmental temperature on growth, food conversion and body composition of channel catfish, Trans. Am. Fish. Soc., 101(1): 94-99.

Banner, A. and J.A. Van Armun, 1973. Thermal effects of eggs, larvae and juveniles of bluegill sunfish, EPA R3-73-041, U.S. EPA, Duluth, Minnesota, p. 111.

Biesinger, K.E., R.P. Brown, C.R. Bernick, G.A. Flittner, and K.E.F. Hokanson, 1979. A national compendium of freshwater fish and water temperature data, Volume 1, Data management techniques, output examples and limitations, Environmental Protection Agency, Report 600/3-79-056, Duluth, Minnesota.

Brett, J.R., 1944. Some lethal temperature relations of algonquin park fishes, Univ. Toronto Stud. Biol., Ser. No. 52, Ontario Fisheries Res. Lab., Toronto, Ontario, p. 49.

Brett, J.R., 1952. Temperature tolerance in young pacific salmon, Genus Oncorhynchus, J. Fish. Res. Board Can., 9: 265-324.

Brown, M.E., 1946. The growth of brown trout (Salmo trutta Linn.) III. The effect of temperature on the growth of two-year-old trout, Journal of Experimental Biology, 22: 145-155.

Charlon, N, B. Barbier and L. Bonnet 1970. Thermal resistance of rainbow trout Salmo gairdneri Richardson to abrupt temperature variations, Ann. Hydrobiol., 1(1), 73-89.

Cherry, D.S., K.L. Dickson, J. Cairns Jr. and J.R. Stauffer, 1977. Preferred, avoided and lethal temperatures of fish during rising temperature conditions, J. Fish. Res. Board Can., 34: 239-246.

Cincotta, D.A., and J.R. Stauffer, Jr., 1984. Temperature preference and avoidance studies of six North American Freshwater Fish Species, Hydrobiologia, 109: 173-177. 
Cvancara, V.A., S.F. Stieber and B.A. Cvancara, 1977. Summer temperature tolerance of selected species of Mississippi river acclimated young of the year fishes, Comp. Biochem. Physiol., 56A: 81-85.

Eaton, J., J.H. McCormick, B.E. Goodno, D.G. O’Brien, K.E.F. Hokanson, H.G. Stefan and M. Hondzo, 1994. A field information database for estimating fish temperature requirements, in press, Fisheries, 20(4), April, 1995.

Efron, B.and G. Gong, 1983. A leisurely look at the Bootstrap, the Jackknife and Cross-validation, The Am. Statistician, 37(1): 36-48.

Frost, W.E. and M.E. Brown, 1967. The Trout, New Naturalist Series, Collins, St. James Place, London, UK.

Fry, F.E.J., J.S. Hart and K.F. Walker, 1946. Lethal temperature relations for a sample of young speckled trout, Salvelinus fontianalus, Univ. Toronto Stud., Biol. Ser. No. 54, Publ. Ontario Fish. Res. Lab., 66: 1-35.

Gammon, J.R., 1971. The response of fish populations in the Wabash River to heated effluents, In: D.J. Nelson (Ed.), 3rd Natl. Symp. Radioecology, U.S. Atomic Energy Comm., 1: 513-523.

Gammon, J.R., 1973. The effect of thermal effluents on the populations of fish and macroinvertebrates in the Wabash River, Technical Report 32, Purdue University, Water Research Center.

Graedel, T.E. and B. Kleiner, 1985. Exploratory analysis of atmospheric data, in Probability, Statistics and Decision Making in the Atmospheric Sciences, edited by A.H. Murphy and R.W. Katz, Westview, Boulder, Colorado, 1-43.

Haan, C.T., 1977. Statistical Methods in hydrology, The Iowa State University Press, Ames, Iowa 50010, p. 378.

Hart, J.S., 1952. Geographical variations of some physiological and morphological characters in certain freshwater fish, Univ. Toronto Biol. Ser. No. 60, Ontario Fisheries Res. Lab., Toronto, Ontario, p. 79.

Hokanson, K.E.F., J.H. McCormick and B.R. Jones, 1973. Temperature requirements for embryos and larvae of the northern pike, Esox lucius, Transactions of the American Fisheries Society, 102(1): 89-100.

Hokanson, K.E.F., C.F. Kleiner and T.W. Thorslund, 1977. Effects of constant temperatures and diel temperature fluctuations on specific growth and mortality rates 
and yield of juvenile rainbow trout, Salmo gairdneri, J. Fish. Res. Board Can., 34(5): 639-648.

Hopkanson, K.E.F. and C.F. Kleiner, 1981. Effects of constant temperatures and diel temperature fluctuations on specific growth and morthality rates and routine metabolism of the black crappie, U.S. EPA Environmental Research Laboratory, Duluth, MN, Unpublished data.

Hokanson, K.E.F. and W.M. Koenst, 1986. Revised estimates of growth requirements and lethal temperature limits of juvenile walleyes, Prog. Fish-Cult., 48: 90-94.

Horning II, W.B. and R.E. Pearson, 1973. Growth temperature requirements and lower lethal temperatures for juvenile smallmouth bass (Micropterus dolomieui). J. Fish. Res. Board Can. 30(8): 1226-1230.

Keast, A., 1985. Growth responses of the brown bullhead (Ictalurus nebulos us) to temperature, Can. J. Zool., 63: 1510-1515.

Kite G.W., 1988. Frequency and risk analysis in hydrology, Water Resources Publications, Littleton, Colorado 80161-2841, p. 257.

Lemke, A.E., 1977. Optimum temperature for growth of juvenile bluegills, Prog. FishCult, 39(2): 55-57.

Martin, J.W., 1966. Early sea life of pink salmon, Proceedings of the 1966 Northeast Pacific Pink Salmon Workshop, W.L. Sheridan (Ed.), State of Alaska Dep. of Fish and Game Information Leaflet \#87: 11-125.

McCormick, J.H., K.E.F. Hokanson and B.R. Jones, 1972. Effects of temperature on growth and survival of young brook trout, Salvelinus fontinalis, J. Fish. Res. Board Can., 29(8): 1107-1112.

McCormick, J.H., 1976. Temperature effects on young yellow perch, Perca flavescens, EPA 600/3-76-057, U.S. EPA, Duluth, Minnesota, p. 18.

McCormick, J.H., B.R. Jones and K.E.F. Hokanson, 1977. White sucker (Catostomus commersoni) embryo development and early growth and survival at different temperatures, J. Fish. Res. Board Can., 34(7): 1019-1025.

McCormick, J.H. and J.A. Wegner, 1981. Responses of largemouth bass from different latitudes to elevated water temperatures, Tran. Am. Fish. Soc. 110: 417-429.

Meuwis, A.L. and M.J. Heuts, 1957. Temperature dependence or breathing rate in carp, Biological Bulletin, 112: 97-107. 
